Mujuzi, J.D. (2016). Victim participation in the criminal justice system in the European Union through private prosecutions: Issues emerging from the jurisprudence of the European Court of Human Rights.

European Journal of Crime, Criminal Law and Criminal Justice, 24: 107 - 134. http://dx.doi.org/10.1163/15718174-24032088

UNIVERSITY of the WESTERN CAPE

\title{
Victim participation in the criminal justice system in the European Union through private prosecutions: Issues emerging from the jurisprudence of the European Court of Human Rights
}

\author{
Jamil Ddamulira Mujuzi
}

\begin{abstract}
Private prosecutions are one of the ways through which crime victims in many European countries participate in the criminal justice system. However, there seems to be a reluctance at the Council of Europe level to strengthen a victim's right to institute a private prosecution. In a 1985 Recommendation, the Committee of Ministers stated that ' $[t]$ he victim should have the right to ask for a review by a competent authority of a decision not to prosecute, or the right to institute private proceeding.' Later in 2000 in the Recommendation Rec (2000)19 on the role of public prosecution in the criminal justice system, the Committee of Ministers calls upon Member States to 'authorise' victims to institute private prosecutions. Directive 2012/29/eu of the European Parliament and of the Council of 25 October 2012 is silent on private prosecutions. The dg Justice Guidance Document related to the transposition and implementation of Directive 2012/29/eu of the European Parliament and of the Council of 25 October 2012 discourages private prosecutions. However, private prosecutions take part in many European countries. It is thus important to highlight some of the issues that have emerged from different European countries on the issue of private prosecutions. Case law from the European Court of Human Rights shows that private prosecutions take place in many European countries. This article, based on case law of the European Court of Human Rights, highlights the following issues with regards to private prosecutions: the right to institute a private prosecution; who may institute a private prosecution? private prosecution after state declines to prosecute; state intervention in a private prosecution; and private prosecution as a domestic remedy which has to be exhausted before a victim of crime approaches the European Court of Human Rights. The author argues that there is a need to recognise the right to private prosecution at the European Union level.
\end{abstract}

\section{$1 \quad$ Introduction}

The general rule is that if a crime is committed, it is the public prosecutor to institute criminal proceedings against a suspect. Jurisprudence emanating from the European Court of Human Rights and from the Court of Justice of the European Union shows that private prosecutions are provided for in many European countries and that some victims of crime have instituted such prosecutions against those who are alleged to have committed offences against them. The Court of Justice of the European Union observed that 'Criminal proceedings in the Member States are, in general, brought by public prosecutors. In exceptional cases, however, private parties, generally the 
victims of crimes, may bring a criminal prosecution before a court in lieu of the public prosecutor and exercise the function of the public prosecutor during the criminal proceedings.' ${ }^{1}$ A private prosecution is one of the ways through which a victim participates in the criminal justice system or may challenge the public prosecutor's decision not to prosecute. Research by the European Union Agency for Fundamental Rights suggests that in 15 European Union countries a victim has a 'right to institute [a] private prosecution' if the public prosecutor has declined to prosecute. ${ }^{2}$ However, there seems to be a reluctance at the European Union and the Council of Europe level to strengthen a victim's right to institute a private prosecution. At paragraph 7 of Recommendation R (85) 11 of the Committee of Ministers to Member States on the Position of the Victim

in the Framework of Criminal Law and Procedure, the Committee of Ministers stated that ' $[t]$ he victim should have the right to ask for a review by a competent authority of a decision not to prosecute, or the right to institute private proceeding.'3 It is clear that at this stage the recommendation was for the victim to have a right to institute a private prosecution should the state decline to prosecute. Fifteen years later, the language of the 'right' was abandoned. Thus paragraph 34 of the Recommendation Rec (2000)19 on the role of public prosecution in the criminal justice system, adopted by the Committee of Ministers on 6 October 2000,4 provides that:

Interested parties of recognised or identifiable status, in particular victims, should be able to challenge decisions of public prosecutors not to prosecute; such a challenge may be made, where appropriate after an hierarchical review, either by way of judicial review, or by authorising parties to engage private prosecution.

In terms of Recommendation Rec (2000)19, Member States no longer have a duty to ensure that victims have a right to institute private prosecutions. They are now required to authorise victims to engage in private prosecutions. Council Framework Decision of 15 March 2001 on the standing of victims in criminal proceedings 5 is also silent on the issue of private prosecutions. The issue of private prosecutions as one of the ways to review a public prosecutor's decision not to prosecute or to participate in the criminal justice system seems to have recently fallen off the agenda of the Council of Europe. For example, Directive 2012/29/eu of the European Parliament and of the Council of 25 October 2012 establishing minimum standards on the rights, support and protection of victims of crime, and replacing Council Framework Decision 2001/220/jha is silent on the issue of private prosecutions notwithstanding the fact that it has many articles on victim participation in the criminal justice system including an article (article 11) entitled 'Rights in the event of a decision not to prosecute.' The Court of Justice of the European Union is yet to develop jurisprudence on Directive 2012/29 and in particular on Article 11. However, there is jurisprudence on the predecessor of Directive 2012/29 some of which is referred to in this article. This jurisprudence

\footnotetext{
${ }^{1}$ Case C-404/07, György Katz v István Roland Sós (Opinion of Advocate General Kokott) (10 July 2008), para. 31.

2 European Union Agency for Fundamental Rights, 'Challenging the decision not to prosecute' (2014), available online at http://fra.europa.eu/en/publications-and-resources/data-and -maps/comparative-data/victims-support-services/prosecution (accessed 2 January 2016).

${ }^{3}$ Adopted by the Committee of Ministers on 28 June 1985 at the 387th meeting of the Ministers' Deputies.

${ }^{4}$ Adopted on 6 October 2000 at the 724th meeting of the Ministers' Deputies.

${ }^{5}$ Council Framework Decision of 15 March 2001 on the standing of victims in criminal proceedings, 2001/220/jha.
} 
has dealt with issues such as the rights of victims to receive compensation from legal parsons; ${ }^{6}$ the taking of evidence from a victim who is a minor; 7 measures to protect vulnerable victims (minors) as witnesses in criminal proceedings ${ }^{8}$ conditions to be imposed on those who commit domestic violence;'9 that 'concept of 'victim' does not extend to legal persons for the purposes of the promotion of mediation in criminal proceedings'; ${ }^{10}$ and that the 'concept of 'victim' for the purposes of the Framework Decision does not include legal persons who have suffered harm directly caused by acts or omissions that are in violation of the criminal law of a Member State.'11 The dg Justice Guidance Document, related to the transposition and implementation of Directive 2012/29/eu of the European Parliament and of the Council of 25 October 2012 establishing minimum standards on the rights, support and protection of victims of crime, and replacing Council Framework Decision 2001/220/jha ${ }^{12}$ seems to be against encouraging Member States to emphasise the right for victims to institute private prosecutions as one of the measures under Article 11 of the Directive 2012/29/eu of the European Parliament and of the Council of 25 October 2012 establishing minimum standards on the rights, support and protection of victims of crime, and replacing Council Framework Decision 2001/220/jha. It states that:

Currently, some national practice applies the system whereby the victim has the right to pursue the prosecution as a private or subsidiary prosecutor (as a consequence of the 'role of the victim in the relevant criminal justice system'). It may be argued that such a concept is not qualitatively - from the perspective of victims' interests - the same as a review set out in Article 11. Becoming a private prosecutor may have its advantages but also constitutes an additional burden on the victim in terms of time, costs etc. Therefore it is questionable if this burden may be mitigated by the provision of free legal aid and other assistance. ${ }^{13}$

Thus, on the basis of paragraph 34 of the Recommendation Rec (2000)19 on the role of public prosecution in the criminal justice system, a private prosecution is one of the ways through which a public prosecutor's decision not to prosecute may be challenged. As the Supreme Court of the United Kingdom observed recently, Private prosecution is, and I think always has been, a safeguard against the feelings of injustice that can arise when, in the eyes of the public, public authorities do not pursue criminal investigations and proceedings in a manner which leads to culprits being brought before a criminal court. The impunity which offenders appear to enjoy can be socially detrimental. This is...particularly so in those cases where a victim actually knows that the offence has been committed but finds that a [public] prosecutor does not think on a balance of likelihood that his evidence, if given orally in court, will be accepted. The feeling of injustice will be particularly acute, if...the [public] prosecutor's decision was a fine one, and the alleged

\footnotetext{
${ }^{6}$ Case C-79/11, Maurizio Giovanardi and Others (12 July 2012) para. 50; See also Case C-79/11, Procura della Repubblica v Maurizio Giovanardi, Andrea Lastini, Filippo Ricci, Vito Piglionica, Massimiliano Pempori, Gezim Lakja, Elettrifer Srl, Rete Ferroviaria Italiana SpA (15 May 2012) para. 71.

${ }^{7}$ Case C-507/10, X v Y (21 December 2011) para. 45. See also Case C-507/10 X v Y (20 October 2011) para. 71.

${ }^{8}$ Case C-105/03, Maria Pupino (16 June 2005) para. 62.

${ }^{9}$ Joined Cases C-483/09 and C-1/10, Magatte Gueye v X; and Valentín Salmerón Sánchez v Y (15 September 2011$)$ para. 71.

${ }^{10}$ Case C-205/09, Emil Eredics v Mária Vassné Sápi (21 October 2010) para. 41(1).

${ }^{11}$ Case C-467/05, Giovanni Dell'Orto v Saipem SpA (28 June 2007) para. 61.

12 Ref. Ares(2013)3763804 - 19/12/2013, available online at http://ec.europa.eu/justice/ criminal/files/victims/guidance_victims_rights_directive_en.pdf.

${ }^{13}$ Page 31.
} 
victims or another prosecutor might equally reasonably have concluded that the case was one in which the evidential test was satisfied.14

In some jurisdictions, such as, the United Kingdom ${ }^{15}$ Germany, ${ }^{16}$ Spain, ${ }^{17}$ and Scotland, ${ }^{18}$ there are policies that stipulate clearly ways through which a victim may petition the prosecuting authority to review a decision not to prosecute.

This article, based on over 100 cases of the European Court of Human Rights, ${ }^{19}$ highlights the issues emerging from the European Court of Human Rights relating to private prosecutions and show the fact that different countries have approached the issue of private prosecutions differently. In the discussion the author deals with the following issues: the right to institute a private prosecution; who may institute a private prosecution; private prosecution after state declines to prosecute; state intervention in a private prosecution; and private prosecution as a domestic remedy. The author argues that there is a need for the right to private prosecution to be strengthened at the European Union level. The reasons for this argument are provided for in the conclusion to this article.

Before one can justify the need for the right to private prosecution in Europe, one fundamental question that one has to answer is whether there is a need for private prosecutions. In answering this question one should bear in mind, as the discussion below illustrates, that private prosecutions are permitted in legislation of many European countries irrespective of whether they adopt the legality principle of prosecution or the opportunity principle of prosecution (these principles are discussed below). It is debatable that they would have been provided for in legislation if they were not needed. As illustrated above and also as some of the case law discussed in this article below shows, private prosecution is one of the ways through which a victim of crime is able to challenge the public prosecutor's decision not to prosecute and also to participate in the criminal justice system. As the Court of Justice of the European Union observed, victims of crime 'generally exercise this function [of private prosecution] precisely because the public prosecutors refuse to bring a prosecution.'20 This ensures that those who commit offences are brought to trial and if convicted, are punished accordingly. This is a fact that has been recognised not only in Europe but also in other parts of the world. ${ }^{21}$ Private prosecutions are also one of the ways to ensure that victims participate in the criminal justice system. Because of the fact that European

\footnotetext{
${ }^{14}$ Gujra, $R$ (on the application of) v Crown Prosecution Service [2013] 1 All er 612 para. 116. See also Financial Times Ltd. \& amp; Ors v Interbrew sa [2002] ewca Civ 274 para. 22.

15 Victims' Right to Review Guidance (2014), available online at https://www.cps.gov.uk/publications/docs/vrr_guidance_2014.pdf.

${ }^{16} \mathrm{~S}$. Reckewerth , 'The of the prosecution in German criminal procedure', 7 Tilburg Foreign Law Review (1998-1999) 65-82, at 77-79.

${ }^{17}$ European judicial systems - Edition 2014 (2012 data) - Efficiency and Quality Justice, cepej Studies No. 20 (2014) 96.

${ }^{18}$ Lord Advocate's Rules: Review of a Decision Not to Prosecute-Section 4 of the Victims and Witnesses (Scotland) Act 2014, available online at http://www.copfs.gov.uk/images/ Documents/Victims_and_Witnesses/Lord\%20Avocates\%20Rules\%20$\% 20$ June $\% 2015 \% 20 \mathrm{v} 2$.pdf.

19 In writing this article, the author read 128 cases from the European Court of Human Rights' online database (http://hudoc.echr.coe.int/eng\#\{“documentcollectionid2":[“GRA NDCHAMBER",“CHAMBER”]\}) in which the phrase "private prosecution' was mentioned. These were the only cases in which the phrase 'private prosecution' was mentioned irrespective of when they were decided and the state in question. It is not clear why some states did not crop up in the search. This database was last visited on 05 February 2016.

${ }^{20}$ Case C-404/07, György Katz v István Roland Sós (Opinion of Advocate General Kokott) (10 July 2008) para. 39.

21 J.D. Mujuzi 'The Right to Institute a Private Prosecution: A Comparative Analysis', 4 International Human Rights Law Review (2015) 222-255.
} 
countries have different principles of prosecution which impact on the issue of private prosecutions differently, it is important to have a look at these principles.

\section{$2 \quad$ Principles of Prosecution}

European countries have adopted one of the two principles of prosecution: the legality principle; or the opportunity (the expediency) principle. It has been argued that:

Adherence to the legality principle in the procedural sense means that the prosecution service cannot exercise any discretion over the prosecutorial decision; prosecution must take place in all reported cases in which there is sufficient evidence of a suspect's guilt, and in which no legal hindrances prohibit prosecution. The principle of opportunity on the other hand, does not demand compulsory prosecution. Instead, it allows the prosecution agency discretion over the prosecutorial decision, even when sufficient evidence exists of the offender's guilt and when no legal hindrances bar proceeding with the matter. ${ }^{22}$

According to Tak, the following European countries have adopted the legality principle: 'Albania, Austria, Bulgaria, Croatia, Germany, Finland, Greece, Hungary, Italy, Ireland, Poland, Portugal, Republic of Belorussia, Romania, Russia, Slovenia, Spain, Sweden, some cantons of Switzerland (for example Bern and Luzern), [and] Turkey.'23 He gives the following as countries which have chosen the opportunity principle: 'Belgium, Cyprus, Denmark, France, Great Britain, Republic of Ireland, Luxembourg, The Netherlands, Norway, [and] some cantons of Switzerland (for example Geneva, Vaud and Neuchatel).'24 Although it may seem that in countries where the legality principle is followed a prosecutor has to prosecute under all circumstances, in practice this is not the case. There are a number of exceptions to the legality principle 'which are designed to soften its rigidity.'25 These exceptions have been discussed by scholars. ${ }^{26}$ Whether or not a country follows a given prosecutorial principle impacts on the circumstances in which a private prosecution, where such prosecutions are permitted, may be instituted. For example, as the discussion below illustrates, in some countries where the opportunity principle is followed (for example in the United Kingdom and in the Republic of Ireland), victims of crime have a right to institute a private prosecution in any case where public prosecutors have declined to prosecute. In countries which follow the legality principle, a private prosecution may only be instituted with respect to minor offences affecting the victim personally. A study by the European Union Agency for Fundamental Rights shows that victims in countries adopting the legality principle and those adopting the expedience principle have a right to institute a private prosecution. The challenge though is that the study indicates that in some countries (for example Cyprus, Estonia, Ireland, Latvia and Greece) victims do not have a right to institute a private prosecution yet case law from the European Court of Human Rights shows that crime victims in those countries have instituted private prosecutions. As the discussion below shows, private prosecutions are also

\footnotetext{
${ }^{22}$ P. Tak, 'East Meets West: Aspects of Prosecution in Countries in Transition', 7 European Journal of Crime, Criminal Law \& Criminal Justice (1999) 412- at 423.

${ }^{23}$ Ibid, 424.

${ }^{24}$ Ibid, 424-425.

${ }^{25}$ Reckewerth, supra note 16 , at 74.

${ }^{26}$ See, for example, Reckewerth, ibid., 75-78; Tak, supra note 22, 425-426; H.-H. Jescheck, 'The Discretionary Powers of the Prosecuting Attorney in West Germany', 18 American Journal of Comparative Law (1970) 508-517; M. Tonry, 'Prosecutors and Politics in Comparative Perspective', 41 Crime and Justice (2012) 1-12, at 10.
} 
provided for in countries which follow the legality principle including Germany. This then brings us to the question of the meaning of a private prosecution. ${ }^{27}$

\section{The Meaning of Private Prosecution}

Private prosecutions mean different things in some countries. However, what is fundamental about them is that a private individual is involved in the prosecution of the offence. As the discussion below shows, there are private prosecutions in which the private prosecutor conducts a prosecution on his or her own. However, in some countries there are cases where a private prosecutor co-prosecutes with the public prosecutor. It is beyond the scope of this paper to give the meaning of private prosecutions in all the European countries in which they exist. Private prosecutions are easier to describe than to define.

It is against this background that the author will attempt to give some of the features of private prosecutions in some European countries. In Austria, some minor offences are only prosecuted by private prosecutors. These include most family violence offences..$^{28}$ Once a private prosecution is instituted, 'a private prosecutor will have to prove all the facts essential for a conviction and cover the costs in case the alleged offender is acquitted.' 29 A crime victim may declare to be a subsidiary prosecutor. $3^{0}$ As the discussion below shows, this is also the case in other countries such as Hungary, Croatia, Macedonia and Serbia. However, it is not the case in the United Kingdom and the Republic of Ireland. In the United Kingdom, a private prosecution is a prosecution not instituted by a public prosecutor (the Crown) or a statutory prosecuting authority. ${ }^{31}$ In the United Kingdom, the Director of Public Prosecutions 'has an express statutory right...to take over any private prosecution. There is no similar provision in Ireland. ${ }^{32}$ A report on the proceedings of the Pan-European Conference of Prosecutors General summarises the meaning and types of private prosecutions in some European countries in the following terms:

The most far-reaching check on the decision of the Public Prosecutor's Office consists in granting the victim the possibility of instituting criminal proceedings himself. A system of private prosecution of this kind is provided for in Belgium, Cyprus, Finland, France, Spain and other countries. The possibility of private prosecution is made subject to one or more restrictions in some Member States. In Scotland, the victim will only be able to institute criminal proceedings himself or herself if he or she has obtained prior judicial permission to do so. In Hungary and Macedonia, private prosecution is only possible for particular crimes...In some Member States, the possibility of a private prosecution is radically rejected. This is the case for example in the Czech Republic, Liechtenstein, Moldova, the Netherlands and Slovakia. The rejection of the system

\footnotetext{
27 European Union Agency for Fundamental Rights, 'Challenging the decision not to prosecute' (2014), available online at http://fra.europa.eu/en/publications-and-resources/data -and-maps/comparative-data/victims-support-services/prosecution (accessed 2 January 2016).

${ }^{28}$ B. Bannenberg and D. Rössner, 'New Developments in restorative justice to handle family violence', in E.G.M. Weitekamp and Hans-Jürgen Kerner (eds) Restorative Justice in Context: International Practice and Directions (2011), pp. 51-79, at p. 65.

29 European Justice, '3 - My rights after the (first) trial-Austria' 5 January 2012. Available online at https://ejustice.europa.eu/content_rights_of_victims_of_crime_in_criminal _proceedings-171-at-maximizemsen.do? clang=en $\&$ idSubpage $=3 \&$ member $=1 \#$ notes 02 .

${ }^{30}$ Ibid.

${ }^{31}$ A. Fairbrother, 'Why, how and when to bring a private prosecution for design right infringement!', 11 June 2015, available online at http://www.lexology.com/library/detail .aspx?g=83d25fe9-55e6-49fd-aeeb-eacaf2877906.

32 Kelly \& Anor v Judge Ryan \& others [2015] iesc 69 (30 July 2015) para. 4.4.
} 
of private prosecution in which the victim himself institutes criminal proceedings and therefore prosecutes does not necessarily imply that the victim would not be involved in the criminal proceedings. The victim in Liechtenstein and the Netherlands, for example, does have the option of joining the Public Prosecutor's Office and having his civil claim to compensation handled in the context of the criminal proceedings. 33

In Hungary once the public prosecutor has declined to prosecute an offence, there are cases where a victim is allowed to institute a private prosecution or a supplementary prosecution. A court will notify the victim after the public prosecutor's decision not to prosecute and a victim has 30 days within which to declare whether he is going to institute a private prosecution or to be supplementary prosecutor. 34 In some countries such as Bosnia and Herzegovina, a public prosecutor has the discretion to discontinue a prosecution and once he has done so 'the victim has no other legal remedy against such a decision of the prosecutor's office.'35 In Denmark, Sweden and Finland a right to institute a private prosecution 'can only be exercised when the public prosecutor decides not to prosecute.' 36 This is also the case in France, Monaco and Slovenia. 37 In Germany, '[i]n the case of certain crimes (trespass minor bodily injury, criminal damage, etc.), the Public Prosecution Office can advise that a private prosecution be pursued if there is no public interest in prosecution; the injured party must then bring a charge himself.' 38 In fact section 374 of the German Code of Criminal Procedure39 provides for the right to institute a private prosecution in respect of many minor offences. In France and Belgium 'the public and private rights to prosecute co-exist in a unique fashion.' 40

In Belgium there are 'strict legal conditions attached to the option of private [which] discourage its use.'41 The above examples show some of the features of private prosecutions in different European countries. Because of the fact that different countries regulate private prosecutions differently, it is apposite to deal with the question of the right to institute a private prosecution and how it has been approached in different European countries.

\section{The Right to Institute a Private Prosecution}

ThegeneralruleinmanyEuropeancountriesisthatanoffencehastobeprosecuted by a public prosecutor. This is the case, for example, in Croatia, ${ }^{42}$ Lithuania, 43 the Republic of Ireland, 44 Finland 45 and the

\footnotetext{
33 Harmonisation and Co-operation Between Prosecutors at European: Proceedings of the second Pan-European Conference of Prosecutors General, Bucharest 12-16 May 2001, (2002) 20-21.

${ }^{34}$ European judicial systems - Edition 2014 (2012 data) - Efficiency and Quality Justice, cepej Studies No. 20 (2014) 96.

${ }^{35} \mathrm{Ibid}, 96$.

${ }^{36}$ D. Kyprianou, The Role of the Cyprus Attorney General's Office in Prosecutions: Rhetoric, Ideology and Practice (Berlin: Springer, 2009), p. 22.

${ }^{37}$ European judicial systems -Edition 2014 (2012 data) - Efficiency and Quality Justice, cepej Studies 20 (Brussels: coe, 2014$)$, at p. 96.

${ }^{38}$ J.-M. Jehle (2015), Criminal Justice in Germany: Facts and Figures (Berlin: Federal Ministry of Justice), at p. 18.

${ }^{39}$ Available online at https://www.gesetze-im-internet.de/englisch_stpo/englisch_stpo .html.

${ }^{40}$ D. Kyprianou, supra note 36, at pp. 22-23.

${ }^{41}$ T. Van Camp, Victims of Violence and Restorative Practices: Finding a Voice (London: Routledge, 2014), p. 49.

${ }^{42}$ Article 8(1) of the Criminal Code (Kazneni zakon, Official Gazette nos. 110/1997, 27/1998, 50/2000, 129/2000, 51/2001, 111/2003, 190/2003, 105/2004, 84/2005, 71/2006, 110/2007, 152/2008, 57/2011). See also Bajić v Croatia (Application No. 41108/10) 13 November 2012 para. 50.
} 
United Kingdom. ${ }^{46}$ This then raises the question of whether a person, especially a crime victim, has a right to institute a private prosecution. The right to institute a private prosecution is neither provided for in any human rights instrument of the European Union nor in any regional or international human rights instrument in the world. 47 As discussed above, the Council of Europe 1985 recommendation which called upon states to ensure that victims have a right to institute private prosecutions has been watered down by subsequent legal developments. However, this right is recognised in many jurisdictions in the world including those in Europe. 48 The European Court of Human Rights held that Article 6 para. 1 [of the European Convention on Human Rights]...did not enshrine any right to bring a criminal prosecution against another person and it was accordingly inapplicable to the private prosecution instituted' by the applicant.49 In other words, the right to a fair trial under Article 6(1) does not include the right to institute a private prosecution. Different European countries have adopted different approaches on this issue. In Croatia, a private prosecution may only be allowed 'in exceptional circumstances.'50 In Finland, 'an injured party may bring a private prosecution only if the public prosecutor has decided not to press charges. ${ }^{51}$ The deceased's legal representative has 'an independent right to bring private prosecution proceedings' against those who allegedly caused his death..$^{2}$ In Ukraine a victim of a minor crime has 'an opportunity' to institute a private prosecution if the public prosecutor has declined to prosecute. 53 In some countries such as Georgia a crime victim or his lawyer are the only ones allowed to institute a private prosecution. 54 The right to institute a private prosecution is provided for in domestic law in countries such as the United Kingdom, 55 Cyprus, ${ }^{56}$ and in the Republic of Ireland.57 In the Republic of Ireland:

Any member of the public, whether an Irish citizen or not, has the right as a "common informer" to bring a private prosecution. He need not have any direct interest in the alleged offence or be personally affected by it. A private prosecutor's rights are limited in respect of offences which are not triable summarily. 58

The Supreme Court of Ireland held recently that the right to institute a private prosecution is entrenched in Irish common law and can only be abolished by an express statutory

\footnotetext{
${ }^{43}$ Borisov v Lithuania (Application No. 9958/04) 14 June 2011 para. 89.

${ }^{44}$ See generally Kelly \& Anor v Judge Ryan \& others [2015] iesc 69 (30 July 2015).

${ }^{45}$ Selistö v Finland (Application No. 56767/00) 16 November 2004 para. 28.

${ }^{46}$ Branson \& Ors v Marrero \& Ors [2010] ew Misc 19 (cc) (7 December 2010) para. 27.

${ }^{47}$ It has been argued that ' $[\mathrm{t}]$ he absence of such a right within international instruments is perhaps explicable by the fact that the concept is largely alien to inquisitorial jurisdictions.' See J. Doak, Victims' Rights, Human Rights and Criminal Justice: Reconceiving the Role of Third Parties (Oxford: Hart, 2008), p. 125.

${ }^{48}$ Mujuzi, supra note 21, at 228-234.

${ }^{49}$ Helmers v Sweden (Application No. 11826/85) 29 October 1991 para. 28.

${ }^{50}$ Article 8(2) of the Criminal Code (Kazneni zakon, Official Gazette nos. 110/1997, 27/1998, 50/2000, 129/2000, 51/2001, 111/2003, 190/2003, 105/2004, 84/2005, 71/2006, 110/2007, 152/2008, 57/2011)). See also Bajić v Croatia (Application No. 41108/10) 13

November 2012 para. 50.

${ }^{51}$ Harju v Finland (Application No. 56716/09) 15 February 2011 para. 22.

52 Selistö v Finland (Application No. 56767/00) 16 November 2004 para. 28.

53 Drozd v Ukraine (Application No. 12174/03) 30 July 2009 para. 22. See also Kozinets v Ukraine (Application No. 75520/01) 6 December 2007 para. 41.

${ }^{54}$ Giorgi Nikolaishvili v Georgia (Application No. 37048/04) 13 January 2009 para. 101.

${ }^{55}$ See generally Gujra, R (on the application of) v Crown Prosecution Service [2013] 1 All er 612.

${ }^{56}$ Andronicou and Constantinou v Cyprus (86/1996/705/897) 9 October 1997 pg 68.

${ }^{57}$ Kelly \& Anor -v-Judge Ryan \& others [2015] iesc 69 (30 July 2015).

${ }^{58}$ Norris v Ireland (Application No. 10581/83) 26 October 1988 para. 17.
} 
provision.59 In Finland the Media Act provides that a person who has been injured by the publication of information about him has the right to institute a private prosecution. ${ }^{60}$ This has been referred to as an 'independent right of private prosecution.'61 In Sweden when the public prosecutor declines to prosecute, the crime victim is entitled to institute a private prosecution. ${ }^{62}$ This is also the case in Austria63 and Ukraine. ${ }^{64}$ The above examples show that there is no uniformity in legislation or practice from different European countries on the crime victim's right to institute a private prosecution. In some countries it is a right and in others it is not although the victim may institute such a prosecution.

Related to the issue of the right to institute a private prosecution is the victim's financial ability to institute such a prosecution. As mentioned above, the issue of costs is one of the reasons why private prosecutions are not seen as an effective way through which victims may challenge the public prosecutor's decision not to prosecute. 65 Private prosecutions could be costly to many people and the European Court of Human Rights observed that private prosecutors 'normally do not benefit from the extensive investigative powers of public prosecutors.' 66 Generally a private prosecutor has to incur the costs of a private prosecution. It is not the responsibility of the state to finance private prosecutions. This is the case, for example, in the United Kingdom ${ }^{67}$ and in Switzerland. ${ }^{68}$ In Croatia there is no legal aid for those conducting private prosecutions. 69 However, in some countries a victim of crime may be offered legal aid to institute a private prosecution. This is the case for example in Poland70 and Spain. ${ }^{71}$ The European Court of Human Rights held that failure by the state to provide legal aid to indigent victims who are not familiar with the law to institute private prosecutions means that private prosecution is not an effective domestic remedy to be exhausted. ${ }^{72}$ In the light of the fact that a private prosecution is instituted because the public prosecutor has declined to prosecute notwithstanding the fact that he is paid from public funds, to which the crime victim may also be a contributor through paying taxes, it would be ideal for the state to provide legal aid to indigent crime victims who have decided to institute private prosecutions. This is especially the case where there is evidence that the alleged perpetrator could have committed the offence. This would strengthen the victim's ability to participate in the criminal justice system meaningfully. Of course this is only applicable to those victims who have decided to institute private prosecutions - those who have the time to do so.

\footnotetext{
${ }^{59}$ Kelly \& Anor -v-Judge Ryan \& others [2015] iesc 69 (30 July 2015).

${ }^{60}$ See Section 17 of the Exercise of Freedom of Expression in Mass Media Act (Act no. 460/2003). Referred to in K.U. v Finland (Application No. 2872/02) 2 December 2008 para. 21.

${ }^{61}$ Nikula v Finland (Application No. 31611/96) 21 March 2002 para. 15.

${ }^{62}$ Helmers v Sweden (Application No. 11826/85) 29 October 1991 para. 14.

${ }^{63}$ Lingens v Austria (Application No. 9815/82) 8 July 1986 para. 26.

${ }^{64}$ Lyashko v Ukraine (Application No. 21040/02) 10 August 2006 para. 38.

65 dg Justice Guidance Document, related to the transposition and implementation of Directive 2012/29/eu of the European Parliament and of the Council of 25 October 2012 establishing minimum standards on the rights, support and protection of victims of crime, and replacing Council Framework Decision 2001/220/jha, page 31.

${ }^{66}$ Y v Latvia (Application No. 61183/08) 21 October 2014 para. 39.

${ }^{67}$ Vella $v$ London Borough of Lambeth \& Anor [2005] ewhe 2473 (Admin) (14 November 2005) para. 23.

${ }^{68}$ Minelli v Switzerland (Application No. 8660/79) 25 March 1983 para. 16

${ }^{69}$ Remetin v Croatia (Application No. 29525/10) 11 December 2012 para. 104.

${ }^{70}$ M.C. v Poland (Application No. 23692/09) 3 March 2015 para. 41 (the court appointed a legal aid lawyer for the applicant).

${ }^{71}$ J. Pérez Gil 'Private interests seeking punishment: Prosecutions brought by private individuals and groups in Spain', 25 Law and Policy (2003) 151-171, at 156.

${ }^{72}$ Remetin v Croatia (Application No. 29525/10) 11 December 2012 para. 104.
} 
Related to the above is the issue of how the crime victim gets to know of his right to institute a private prosecution. In Latvia, the inspector of police, should the victim's complaint against a police officer be dismissed, informs the victim that he can institute a private prosecution against the police officer and also informs the victim the time within which that prosecution has to be instituted.73 In Ukraine the police informed the victim that he may institute a private prosecution against the alleged perpetrators as the police were not going to have them prosecuted for lack of evidence.74 In some countries when the public prosecutor declines to prosecute the alleged offence, he/she will advise the victim to institute a private prosecution against the alleged perpetrator. This is the case, for example, in Lithuania,75 Ukraine ${ }^{76}$ and Latvia. 77

It is also important that the victim knows that process that has to be followed to institute a private prosecution. There are different systems in different countries. In Latvia the victim approaches the court directly to institute a private prosecution. ${ }^{78}$ Thejudge will then investigate the matter and establish whether the victim's statement 'contains a correct indication of the section and paragraph of the Criminal Law on the basis of which criminal proceedings are to be initiated in a private prosecution case, and whether or not a statutory limitation has entered into effect.'79 In order to prove his case, the victim may ask the 'judge to call witnesses and to obtain other materials.' 80 In Croatia there is a difference between a private prosecution on the one hand and a prosecution conducted by a crime victim after the public prosecutor has declined to prosecute. As the court stated:

The Croatian legal system also allows the injured party to act as a subsidiary prosecutor. In respect of criminal offences for which the prosecution is to be undertaken by the State Attorney's Office, either of its own motion or on a private application, where the Office declines to prosecute on whatever ground, the injured party may take over the prosecution as a subsidiary prosecutor. In contrast, a private prosecution is undertaken from the beginning by a private prosecutor. ${ }^{81}$

This is also the position Macedonia ${ }^{82}$ Hungary, ${ }^{83}$ Serbia $^{84}$ and Austria. ${ }^{85}$ In Georgia, a private prosecution complaint has to be signed by the victim or his representative otherwise the court will

\footnotetext{
${ }^{73}$ Y v Latvia (Application No. 61183/08) (21 October 2014) para. 19.

${ }^{74}$ Skorokhodov v Ukraine (Application No. 56697/09) (14 November 2013) para. 16.

${ }^{75}$ Borisov v Lithuania (Application No. 9958/04) 14 June 2011 para. 75; Valiulienè v Lithuania (Application No. 33234/07) 26 March 2013 para. 11.

${ }^{76}$ Drozd v Ukraine (Application No. 12174/03) 30 July 2009 para. 22; Gordiyenko v Ukraine (Application No. 27620/09) 16 October 2014 para. 12; Skorokhodov v Ukraine (Application No. 56697/09) 14 November 2013 para. 16.

77 Y v Latvia (Application No. 61183/08) 21 October 2014 para. 19.

${ }^{78}$ Ibid.

${ }^{79}$ Y v Latvia (Application No. 61183/08) (21 October 2014) para. 30.

${ }^{80}$ Y v Latvia (Application No. 61183/08) (21 October 2014) para. 31.

${ }^{81}$ Beganović v Croatia (Application No. 46423/06) 25 June 2009 para. 73. See also D.J. v Croatia (Application No. 42418/10) 24 July 2012 para. 47; Remetin v Croatia (No. 2) (Application No. 7446/12) 24 July 2014 paras 56 and 101; Bilbija and Blažević v Croatia (Application No. 62870/13) (12 January 2016) para. 76.

${ }^{82}$ El-Masri v The Former Yugoslav Republic Of Macedonia (Application No. 39630/09) 13 December 2012 para. 85.

${ }^{83}$ Gubacsi v Hungary (Application No. 44686/07) 28 June 2011 para. 24; Haász and Szabó v Hungary (Application Nos 11327/14 and 11613/14) 13 October 2015 paras 18 and 22; Case C-404/07, György Katz v István Roland Sós (Opinion of Advocate General Kokott) (10 July 2008) para. 22.

${ }^{84}$ Isaković Vidović v Serbia (Application No. 41694/07) 1 July 2014 para. 62.

${ }^{85}$ Falter Zeitschriften gmbh v Austria (no. 2) (Application No. 3084/07) 18 September 2012 para. 8.
} 
dismiss it. ${ }^{86}$ Therefore, apart from the recognition of the victim's right to institute a private prosecution, the environment should also be conducive for his or her to institute such a prosecution. For example, legal aid should be provided for the indigent victims and the relevant information regarding the process to be followed in instituting private prosecutions should also be provided for the victims.

\section{$5 \quad$ Who May Institute a Private Prosecution?}

In many European countries it is the victim of the alleged crime who may institute a private prosecution. This is the case, for example, in Latvia, ${ }^{87}$ Cyprus, ${ }^{88}$ Albania, ${ }^{89}$ Estonia, ${ }^{90}$ Latvia, ${ }^{11}$ Lithuania 92 and Croatia.93 However, in Lithuania although a victim may institute a private prosecution in respect of minor bodily injuries, 'a public prosecutor retains the right to open a criminal investigation into acts causing minor bodily harm, if the crime is of public importance or the victim is not able to protect his or her interests.' 94 One of the judges of the European Court of Human Rights held in the context of Cyprus, that: 'Unlike the position in Ireland..., there is no actio popularis in Cyprus. Only the victim of a crime can mount a private prosecution...Only a party injured by criminal conduct is in law entitled to raise a private prosecution.'95 In some countries juristic persons may institute private prosecutions. This is the case, for example, in the United Kingdom 96 and Germany. 97

In Switzerland courts held that an association can only bring a private prosecution if it can show that it was a victim of a crime. $9^{8}$ In Spain, a professional association can institute a private prosecution on behalf of one of its members. 99 In the Republic of Ireland a juristic person has no common law right to institute a private prosecution unless such a right is conferred upon it by a statute. ${ }^{100}$ It is only natural persons with the common law right to institute private prosecutions. The deceased's estate may continue with the private prosecution he initiated before his death. ${ }^{101}$ In Spain a private prosecution can only be instituted by citizens. ${ }^{102}$ In Azerbaijan a refugee may institute a private prosecution ${ }^{103}$ and in Ireland both citizens and non-citizens. ${ }^{104}$ The above discussion shows that different countries have adopted different approaches on the issue of who may institute a private prosecution. In all countries natural persons may institute private prosecutions. In some countries only natural persons as opposed to juristic persons may

\footnotetext{
${ }^{86}$ Giorgi Nikolaishvili v Georgia (Application No. 37048/04) 13 January 2009 para. 12.

${ }^{87}$ Y v Latvia (Application No. 61183/08) (21 October 2014) para. 19.

${ }^{88}$ Andronicou and Constantinou v Cyprus (86/1996/705/897) 9 October 1997, para. 68.

${ }^{89}$ Qama v Albania and Italy (Application No. 4604/09) 8 January 2013 para. 49.

90 Tammer v Estonia (Application No. 41205/98) 6 February 2001 para. 27.

${ }^{91}$ Y v Latvia (Application No. 61183/08) 21 October 2014 paras 19 and 30.

${ }_{92}$ Valiulienè v Lithuania (Application No. 33234/07) 26 March 2013 paras 21 and 35.

${ }^{93}$ M.S. v Croatia (Application No. 36337/10) 25 April 2013 para. 64.

${ }^{94}$ Valiulienè v Lithuania (Application No. 33234/07) 26 March 2013 para. 78.

${ }_{95}$ Modinos v Cyprus (Application No. 15070/89) 22 April 1993 pages 19 - 20 (Dissenting Opinion of Judge Pikis).

${ }^{96}$ Virgin Media Ltd, R (on the application of) v Zinga [2014] 1 wlr 2228 paras 15-16; Rollins, R. v [2009] ewca Crim 1941.

${ }^{97}$ Article 374(3) of the German Code of Criminal Procedure.

98 Perinçek v Switzerland (Application No. 27510/08) 15 October 2015 paras 41-44.

99 Tejedor García v Spain (142/1996/761/962) 16 December 1997 paras 8 and 25.

${ }^{100}$ Kelly \& Anor -v-District Judge Ann Ryan [2013] iehc 321 (9 July 2013) para. 21.

${ }^{101}$ Aho v Finland (Application No. 2511/02) 16 October 2007 para. 17.

102 Article 125 of the Constitution of Spain. See also Julio Pérez Gil, supra note 71, 152.

${ }^{103}$ Fatullayev v Azerbaijan (Application No. 40984/07) 22 April 2010 para. 97-99 and 139. See also Insanov v Azerbaijan (Application No. 16133/08) 14 March 2013.

${ }^{104}$ Norris v Ireland (Application No. 10581/83) 26 October 1988 para. 17.
} 
institute private prosecutions. In others both natural persons and juristic persons may institute private prosecutions. In Spain only citizens may institute private prosecutions. In Azerbaijan and in Ireland even non-citizens may institute private prosecutions.

Closely related to the question of who may institute a private prosecution is the question of the person or persons against whom a private prosecution may be instituted. In some countries there are limitations on the people against whom a private prosecution may be brought. In Croatia, a private prosecution may not be instituted against a minor. ${ }^{105}$ Juveniles can only be prosecuted by public prosecutors. ${ }^{106}$ This is also the case in Spain ${ }^{107}$ and in Germany. ${ }^{108}$ In the Republic of Ireland a private prosecution cannot be instituted against a spouse for marital rape without the consent of the dpp. ${ }^{109}$ In the United Kingdom a private prosecution may not be instituted against a person who committed some international crimes without the consent of the dpp. ${ }^{110}$ Legislation to the sameeffect existsin Belgium and Spain. ${ }^{111}$

\section{Private Prosecution after State Declines to Prosecute}

In many countries and in respect of many offences, a private prosecution can only be instituted after the state has declined to prosecute the alleged offender. This is the case, for example, in Hungary, ${ }^{112}$ Finland, ${ }^{113}$ the Republic of Ireland ${ }^{114}$ and the United Kingdom. ${ }^{115}$ The state's refusal to prosecute the alleged perpetrator could be informed by the lack of evidence as has been the case in some countries such as Latvia, ${ }^{116}$ Ukraine ${ }^{117}$ and Finland. ${ }^{118}$ However, in some countries and with regard to some offences, a private prosecution can be brought before the state has declined to prosecute the alleged offender. For example, Croatian law provides that some offences can only be prosecuted by a private prosecutor. Article $102^{119}$ of the Croatian Criminal Code ${ }^{120}$ provides that 'Criminal proceedings for the offence of inflicting bodily injury (Article 98) ${ }^{121}$ shall be instituted by means of private prosecution.' ${ }^{122}$ These are 'criminal offences of a lesser nature. ${ }^{123}$ The position is the same in Lithuania ${ }^{124}$ and Latvia. ${ }^{125}$ In Poland, the offences of minor

\footnotetext{
105 Beganović v Croatia (Application No. 46423/06) 25 June 2009 paras 17 and 20.

106 Beganović v Croatia (Application No. 46423/06) 25 June 2009 para. 20.

${ }^{107}$ Pérez Gil, supra note 71, 157.

108 Jehle, supra note 38 , at p. 18.

${ }^{109}$ Section 5(2) of the Criminal Law (Amendment) Act 1990. See Kelly \& Anor v District Judge Ann Ryan [2013] iehc 321 (09 July 2013) para. 18 where this provision is interpreted.

${ }^{110}$ Section 153(1)(4A) of the Police Reform and Social Responsibility Act 2011.

${ }^{111}$ See 'Recent Legislation', 125 Havard Law Review (2012) 1554-1561, 1557.

112 Balázs v Hungary (Application No. 15529/12) 20 October 2015, para. 27-29.

113 Heino v Finland (Application No. 56720/09) 15 February 2011 para. 21; Huohvanainen v Finland (Application No. 57389/00) 13 March 2007 para. 51; Petri Sallinen and Others v Finland (Application No. 50882/99) 27 September 2005 para. 50.

${ }^{114}$ Kelly \& Anor v District Judge Ann Ryan [2013] iehc 321 (9 July 2013).

115 Campbell and Fell v The United Kingdom (Application No. 7819/77; 7878/77) 28 June 1984 para. 30; Malone v The United Kingdom (Application No. 8691/79) 2 August 1984 para. 57(1).

${ }^{116}$ Y v Latvia (Application No. 61183/08) (21 October 2014) para. 18.

117 Skorokhodov v Ukraine (Application No. 56697/09) (14 November 2013) para. 16.

${ }^{118}$ Harju v Finland (Application No. 56716/09) 15 February 2011 para. 22.

119 A v Croatia (Application No. 55164/08) 14 October 2010.

120 Criminal Code (Kaznenei zakon Republike Hrvatske, Official Gazette nos. 110/1997, 28/1998, 50/2000, 129/2000, 51/2001, 11/2003, 105/2004, 84/2005 and 71/2006). Referred to in A v Croatia (Application No. 55164/08) 14 October 2010 para. 41.

${ }^{121}$ Article 98.

122 See also M.S. v. Croatia (Application No. 36337/10) 25 April 2013 para. 67.

${ }^{123}$ Beganović v Croatia (Application No. 46423/06) 25 June 2009 para. 72. See also D.J. v Croatia (Application No. 42418/10) 24 July 2012 para. 87.

${ }^{124}$ Borisov v Lithuania (Application No. 9958/04) 14 June 2011 para. 89.

${ }^{125}$ Y v Latvia (Application No. 61183/08) 21 October 2014 para. 17.
} 
assault and defamation 'can only be prosecuted by means of private prosecution.' ${ }^{126}$ In Serbia, most serious offences have to be prosecuted by public prosecutors 'but some minor offences were only subject to private prosecution. ${ }^{127}$ This is also the case in Russia. ${ }^{128}$ In Georgia, the offence of libel 'is a matter for private prosecution. ${ }^{\prime 29}$ In Ukraine minor offences may be prosecuted by private prosecutors. ${ }^{130}$ In Croatia, a private prosecution cannot be instituted with regard to serious offences such as rape. ${ }^{131}$ In Latvia 'a private prosecution could only be initiated in cases [such as]... intentional infliction of minor bodily injuries (with or without damage to health) or torture.' ${ }^{132}$ In Azerbaijan, article 37.2 of the Criminal Procedure Code provides that:

A private criminal prosecution shall take place only upon a complaint by the victim concerning offences under Articles 147 [defamation], 148 [insult], 165.1 [infringement of copyrights and related rights] and 166.1 [infringement of patent and invention rights] of the Criminal Code and shall be discontinued in the event of reconciliation between the victim and the accused before the court deliberates. ${ }^{133}$

The above discussion shows that two different approaches have been taken with regard to private prosecutions. The first approach is to the effect that a private prosecution will only take place once the public prosecutor has declined to prosecute. This is the case whether the offence is a serious one or minor. The second approach is that in some countries minor offences are not prosecuted by public prosecutors. They have to be prosecuted by private prosecutors otherwise such offences will not be prosecuted. Practice from many European countries shows that private prosecutions have been instituted especially for minor offences. These have included infliction of minor bodily injury in (Latvia, ${ }^{134}$ Ukraine, ${ }^{135}$ Bulgaria ${ }^{136}$ and Croatia), ${ }^{137}$ defamation

(Austria ${ }^{138}$ Lithuania, ${ }^{139}$ France, ${ }^{140}$ Serbia, ${ }^{141}$ Azerbaijan, ${ }^{142}$ Sweden, ${ }^{143}$ Bulgaria, ${ }^{144}$ Poland, ${ }^{145}$ Ukraine, ${ }^{146}$ Macedonia ${ }^{147}$ and Latvia ${ }^{148}$ ), insult (Austria ${ }^{149}$ Bulgaria ${ }^{150}$ and Estonia) ${ }^{151}$ libel (Georgia, ${ }^{152}$ Hungary, ${ }^{153153}$

\footnotetext{
${ }^{126}$ Husayn (Abu Zubaydah) v Poland (Application No. 7511/13) 24 July 2014 para. 179. See also M.C. v. Poland (Application No. 23692/09) 3 March 2015 para. 108; Al Nashiri v Poland (Application No. 28761/11) 24 July 2014 para. 185.

127 Đekić and Others v Serbia (Application No. 32277/07) 29 April 2014 para. 16; Otašević v Serbia (Application No. 32198/07) 5 February 2013 para. 18; Stanimirović v Serbia (Application No. 26088/06) 18 October 2011 para. 23.

${ }^{128}$ Makhashevy v Russia (Application No. 20546/07) 31 July 2012 para. 91.

${ }^{129}$ Giorgi Nikolaishvili v Georgia (Application No. 37048/04) 13 January 2009 para. 10.

${ }^{130}$ Drozd v Ukraine (Application No. 12174/03) 30 July 2009 para. 22.

${ }^{131}$ D.J. v Croatia (Application No. 42418/10) 24 July 2012 para. 87.

${ }^{132}$ Leja v Latvia (Application No. 71072/01) 14 June 2011 para. 53.

${ }^{133}$ Referred to in Tahirova v Azerbaijan (Application No. 47137/07) 3 October 2013 para. 25.

134 Y v Latvia (Application No. 61183/08) (21 October 2014) paras 19-20.

135 Skorokhodov v Ukraine (Application No. 56697/09) (14 November 2013) para. 16; Gordiyenko v Ukraine (Application No. 27620/09) 16 October 2014 para. 12; Pelevin v Ukraine (Application No. 24402/02) 20 May 2010 para. 8.

136 Abdu v Bulgaria (Application No. 26827/08) 11 March 2014 para. 36; Bevacqua and S. v Bulgaria (Application No. 71127/01) 12 June 2008 para. 38; The United Macedonian Organisation Ilinden and Ivanov v Bulgaria (No. 2) (Application No. 37586/04) 18 October 2011 para. 70.

${ }^{137}$ A v Croatia (Application No. 55164/08) 14 October 2010.

138 Section 8(a) para. 1 of the Media Act. Referred to in A.T. v Austria (Application No. 32636/96) 21 March 2002 para. 20. See also Armellini and Others v Austria (Application No. 14134/07) 16 April 2015 para. 11; Kobenter and Standard Verlags gmbh v Austria (Application No. 60899/00) 2 November 2006 para. 10; Krone Verlags gmbh \& Co kg v Austria (No. 4) (Application No. 72331/01) 9 November 2006 para. 12; Lechner and Hess v Austria 11/1985/97/145 para. 18; Lingens v Austria (Application No. 9815/82) 8 July 1986 para. 20; Nikowitz and Verlagsgruppe News gmbh v Austria (Application No. 5266/03) 22 February 2007 para. 7; Oberschlick v Austria (Application No. 11662/85) 23 May 1991 para. 14; Genner v Austria (Application No. 55495/08) (12 January 2016$)$ para. 10.

${ }^{139}$ Borisov v Lithuania (Application No. 9958/04) 14 June 2011 para. 76.
} 
Poland, ${ }^{154}$ and Sweden) ${ }^{155}$ manslaughter (Finland), ${ }^{156}$ slander (Poland), 157 abuse of office by judges (Finland), ${ }_{158}$ ill treatment (Hungary ${ }^{159}$ and Poland) ${ }^{160}$ and using an illicit access device to watch football matches (United Kingdom). ${ }^{161}$ There is also evidence that in the Republic of Ireland an individual was convicted after a private prosecution. ${ }^{162}$

\section{$7 \quad$ State Intervention in a Private Prosecution}

In some countries a public prosecutor may take over and discontinue a private prosecution. This should be understood against the background that private prosecutions may and have been abused and that in many countries the general rule is that an offence has to be prosecuted by a public prosecutor. There have been cases in some European countries where private prosecutions have been abused. The abuse included instituting a private prosecution against a person without notifying him of the prosecution to defend himself; 163 and instituting a private prosecution after the expiry of the period within which it should have been instituted. ${ }^{164}$ In the United Kingdom, in the case of CrawfordAdjusters\&OrsvSagicor GeneralInsurance(Cayman)Ltd\&Anor(Cayman Islands) ${ }^{165}$ Lord Sumption observed that ' $[\mathrm{t}]$ he tort of malicious prosecution was created in the seventeenth and eighteenth centuries to deal with the problem of abusive private prosecutions, which was then a serious social evil...' ${ }^{166}$ In order to, inter alia, prevent or end the abuse of private prosecutions, measures have been put in place for state officials to intervene. In Cyprus, ${ }^{167}$ 'the victim of a crime has the right to take a private prosecution...subject only to

\footnotetext{
${ }^{140}$ Chauvy and Others v France (Application No. 64915/01) 29 June 2004 para. 14.

${ }^{141}$ Isaković Vidović v Serbia (Application No. 41694/07) 1 July 2014 para. 9.

142 Fatullayev v Azerbaijan (Application No. 40984/07) 22 April 2010 paras 18 and 97-99. See also Mahmudov and Agazade v Azerbaijan (Application No. 35877/04) 18 December 2008 para. 9.

143 Helmers v Sweden (Application No. 11826/85) 29 October 1991 para. 14; White v Sweden (Application No. 42435/02) 19 September 2006 para. 6.

${ }^{144}$ Lolova-Karadzhova v Bulgaria (Application No. 17835/07) 27 March 2012 para. 6.

145 Łopuch v Poland (Application No. 43587/09) 24 July 2012 para. 21.

${ }^{146}$ Lyashko v Ukraine (Application No. 21040/02) 10 August 2006 para. 52; Marchenko v Ukraine (Application No. 4063/04) 19 February 2009 para. 17.

${ }^{147}$ Popovski v The Former Yugoslav Republic of Macedonia (Application No. 12316/07) 31 October 2013 para. 9.

148 Beiere v Latvia (Application No. 30954/05) 29 November 2011 para. 6.

${ }^{149}$ Freiheitliche Landesgruppe Burgenland v Austria (Application No. 34320/96) 18 July 2002 para. 11.

${ }^{150}$ The United Macedonian Organisation Ilinden and Ivanov v Bulgaria (No. 2) (Application No. 37586/04) 18 October 2011 para. 70.

151 Tammer v Estonia (Application No. 41205/98) 6 February 2001 para. 23.

152 Giorgi Nikolaishvili v Georgia (Application No. 37048/04) 13 January 2009 para. 10.

153 Karakó v Hungary (Application No. 39311/05) 28 April 2009 para. 10.

${ }^{154}$ Kuśmierek v Poland (Application No. 10675/02) 21 September 2004 para. 7; Nowicka v Poland (Application No. 30218/96) 3 December 2002 para. 12.

${ }^{155}$ Holm v Sweden (Application No. 14191/88) 25 November 1993 para. 9.

${ }^{156}$ Huohvanainen v Finland (Application No. 57389/00) 13 March 2007 para. 51.

${ }^{157}$ Ladent v Poland (Application No. 11036/03) 18 March 2008 para. 8.

${ }^{158}$ Lönnholtz v Finland (Application No. 60790/00) 25 April 2006 para. 7.

${ }^{159}$ László Károly v Hungary (No. 2) (Application No. 50218/08) 12 February 2013 para. 9; Réti and Fizli v Hungary (Application No. 31373/11) 25 September 2012 para. 11.

160 M.C. v Poland (Application No. 23692/09) 3 March 2015 para. 41.

161 Cases C-403/08 and C-429/08, Football Association Premier League Ltd and Others v qc Leisure and Others; Karen Murphy v Media Protection Services Ltd (Opinion of Advocate General Kokott) 3 February 2011 (1) para. 42.

${ }^{162}$ Case C-580/08 P, Devrajan Srinivasan v European Ombudsman (Order of the Court) (Sixth Chamber), 25 June 2009 para. 19.

${ }^{163}$ Ladent v Poland (Application No. 11036/03) 18 March 2008 para. 56.

${ }^{164}$ Pieniążek v Poland (Application No. 62179/00) 28 September 2004 para. 11.

165 Crawford Adjusters \& Ors v Sagicor General Insurance (Cayman) Ltd \& Anor (Cayman Islands) [2013] ukpc 17 (13 June 2013)

[2013] ukpc 17, [2013] 6 Costs lo 826, [2013] 3 wlr 927, [2014] 1 ac 366, [2014] ac 366, [2013] wlr(D) 229, [2013] 4 All er 8.

166 Ibid., para. 121.

${ }^{167}$ Andronicou and Constantinou v Cyprus (86/1996/705/897) 9 October 1997 p. 68.
} 
the right of the Attorney-General to take over and continue or discontinue any such proceedings at his discretion.'168However, the Attorney-General cannot stop a private prosecution from being instituted. All he can do is to wait for it to be instituted and take it over and discontinue it. ${ }^{169}$ In Spain, a private prosecution and a public prosecution may be instituted against the accused simultaneously. In other words, the accused may be prosecuted by both the private prosecute and the public prosecutor for the same offence based on the same facts. ${ }^{170}$ In Estonia a public prosecutor has a right to participate in a private prosecution and a court will invite him or her to participate. ${ }^{171}$ In the Republic of Ireland, a private prosecution is instituted so that it can be taken over by the public prosecutor. In the United Kingdom, there are circumstances in which a public prosecutor may take over and discontinue a private prosecution. The Supreme Court of the United Kingdom held that the power of the Director... to undertake the conduct of a prosecution instituted by a private prosecutor comprises a power to undertake its conduct in order not only to continue it but also to discontinue it. ${ }^{172}$

\section{$8 \quad$ Private Prosecution as a Domestic Remedy}

One of the requirements that have to be met for a case to be admissible by the European Court of Human Rights is that the applicant should have exhausted domestic remedies. ${ }^{173}$ For the victim's application for non-exhaustion of domestic remedies to be dismissed because of the possibility of instituting a private prosecution, the government must plead that fact expressly. 174 The victim should not be expected to conduct a private prosecution when the state is also in the process of prosecuting the offender based on the same facts. ${ }^{175} \mathrm{~A}$ private prosecution will be a domestic remedy if it is effective and 'capable

of fulfilling the State's procedural obligations.' ${ }^{176}$ In other words, it should be adequate and effective.177 In cases of domestic violence, the Court 'considers that the possibility for the...applicant to bring private prosecution proceedings and seek damages was not sufficient as such proceedings obviously required time and could not serve to prevent recurrence of the incidents complained of.' ${ }^{178}{ }^{7}$ The Court held that for a private prosecution to be exhausted as a domestic remedy, it has to be proved that 'it was capable of providing any redress to the applicant in relation to the complaint' in question. ${ }^{179}$ If the government argues that the applicant should have instituted a private prosecution, it has to adduce evidence of successful private prosecutions. Otherwise the court will find the remedy of private prosecution to be ineffective. ${ }^{180}$ For example, in Haász and Szabó $v$

\footnotetext{
${ }^{168}$ Ibid., Modinos v Cyprus (Application No. 15070/89) 22 April 1993 para. 12.

${ }^{169}$ Modinos v Cyprus (Application No. 15070/89) 22 April 1993 para. 12.

${ }^{170}$ Barberà, Messegué and Jabardo v Spain (Application No. 10590/83) 6 December 1988. See also Julio Pérez Gil 'Private interests seeking punishment: Prosecutions brought by private individuals and groups in Spain' (2003) 25 Law and Policy 151-171.

171 Tammer v Estonia (Application No. 41205/98) 6 February 2001 para. 56.

172 Gujra, R (on the application of) v Crown Prosecution Service [2013] 1 Cr App R 12, [2012] 3 wlr 1227, [2013] 1 All er 612, [2013] 1 ac 484, [2012] wlr(D) 330, [2012] uksc 52 para. 15.

173 Article 35 of the European Convention on Human Rights.

${ }^{174}$ Y v Latvia (Application No. 61183/08) (21 October 2014) para. 40.

175 Skorokhodov v Ukraine (Application No. 56697/09) (14 November 2013) para. 36.

176 Abdu v Bulgaria (Application No. 26827/08) 11 March 2014 para. 36. See also Bazjaks v Latvia (Application No. $71572 / 01)$ 19 October 2010 para. 125; Borbála Kiss v Hungary (Application No. 59214/11) 26 June 2012 para. 26.

${ }_{177}$ Denizci and Others v Cyprus (Applications nos. 25316-25321/94 and 27207/95) 23 May 2001 paras 355-357.

${ }^{178}$ Bevacqua and S v Bulgaria (Application No. 71127/01) 12 June 2008 para. 83.

${ }^{179}$ Bazjaks v Latvia (Application No. 71572/01) 19 October 2010 para. 91.

${ }^{180}$ Egmez v Cyprus (Application No. 30873/96) 21 December 2000 para. 99.
} 
Hungary ${ }^{181}$ one of the reasons why the court declared the applicant's complaint admissible notwithstanding the fact that she had not instituted a private prosecution against the police officers who had ill-treated her, was because in the applicant's county 'only two actual trials had resulted from the total of eleven substitute private prosecutions initiated in the period between 2006 and 2010.' 182

The applicant is not required to institute a private prosecution as one of the domestic remedies if he 'brought the substance of his complaint to the notice of the national authorities and as having sought redress through the national channels for his complaint. ${ }^{183}$ However, this is not a unanimous view. ${ }^{184}$ The fact that the applicant instituted a private prosecution and the alleged offender was not convicted does not mean that private prosecution is not an effective remedy. As the Court put it ' $\mathrm{t}$ ] he mere fact that the outcome of those [private] criminal proceedings was not in the applicant's favour, does not render them ineffective.' ${ }^{185}$ The Court has also held that in cases of ill-treatment by government officials, victims are not required to institute private prosecutions before approaching the Court. As the Court has held in the context of Hungary: 'victims are not required to pursue the prosecution of officers accused of ill-treatment on their own, this being a duty of the public prosecutor who is certainly better, if not exclusively, equipped in that respect.' 186 The above jurisprudence shows that the European Court of Human Rights will examine the law, procedure and practice relating to private prosecutions in a given country generally and the applicant's case particularly in deciding whether or not it was a domestic remedy that had to be exhausted before the applicant approached the Court. If it is available as a domestic remedy it has to be exhausted before the Court is approached.

\section{Conclusion}

In this article the author, relying mainly on case law from the European Court of Human Rights, has dealt with the question of private prosecution in many European countries. In the light of the fact that private prosecutions are provided for in many European countries, there may be a need for the European Union to come up with guidelines addressing the important aspects of private prosecutions. Issues could include some of those highlighted in this article. It was pointed above that there is a need for the victim's right to institute a private prosecution to be provided for at the Europe Union level. In the author's view, it is not enough for the victim to have an opportunity to institute a private prosecution. This is because once it is provided for that a victim has a right to institute a private prosecution; three obligations would be imposed on European states: one, the obligation to protect that right; two, the obligation to promote that right; and three, the obligation to fulfil that right. These obligations would require states to adopt comprehensive measures to ensure that that right is given effect to and that the rights of the

\footnotetext{
${ }^{181}$ Haász and Szabó v Hungary (Application Nos 11327/14 and 11613/14) 13 October 2015.

182 Haász and Szabó v Hungary (Application Nos 11327/14 and 11613/14) 13 October 2015 para. 28. See also Heino v Finland (Application No. 56720/09) 15 February 2011 para. 53.

183 Balázs v Hungary (Application No. 15529/12) 20 October 2015 para. 32. See also Haász and Szabó v Hungary (Application Nos 11327/14 and 11613/14) 13 October 2015 para. 32; Sandra Janković v Croatia (Application No. 38478/05) 5 March 2009 para. 37.

184 Haász and Szabó v Hungary (Application Nos 11327/14 and 11613/14) 13 October 2015, see Concurring Opinion of Judge Lemmens.

${ }^{185}$ Borisov v Lithuania (Application No. 9958/04) 14 June 2011 para. 125.

${ }^{186}$ Haász and Szabó v Hungary (Application Nos 11327/14 and 11613/14) 13 October 2015 para. 30. See also Jasiński v Poland (Application No. 72976/01) 6 December 2007 para. 28.
} 
accused are protected during these private prosecutions. These measures could include legal aid to victims who cannot afford to institute private prosecutions; police providing to the private prosecutor the information or evidence in their possession that could help him/her to institute a private prosecution; the obligations imposed

on public prosecutors with regards to the evidence in their possession that could strengthen a private prosecution; and reimbursing private prosecutors the expenses incurred in cases of successful private prosecutions. The Court of Justice of the European Union has highlighted some of the challenges faced by victims of crime who institute private prosecutors and has held that they 'deserve special protection' in the criminal justice system. The Court observed that:

[I]t is specifically victims bringing prosecutions who deserve special protection. They generally exercise this function precisely because the public prosecutors refuse to bring a prosecution. In such a situation, a prohibition of testimony would amount to an additional disadvantage: victims would have to conduct the proceedings alone, without the support of a public prosecutor, and would, at the same time, be deprived of important evidence... It would be difficult, if not impossible, to succeed with a private prosecution if the prosecuting victim were not able to give testimony. 187

However, like many other rights, the right to institute a private prosecution should not be an absolute right. There should be limitations imposed on it. As the Court of Justice of the European Union observed, in exceptional circumstances victims of crime may institute private prosecutions. 'This procedure raises the question to what extent rules governing public prosecutors are also applicable to parties bringing a private prosecution. This relates both to the powers of the prosecutor and to any limitations on them.' ${ }^{188}$ The Court observes that in Hungarian law there are limitations imposed on private prosecutors. ${ }^{189}$ The limitations imposed on private prosecutors must be justified in democratic societies, that is, they should not be arbitrary. One important limitation would be that this right only arises in cases where the public prosecutor is unable or unwilling to prosecute. In other words, the right and duty to prosecute any offence should first be waived by the public prosecutor before a private prosecution may be instituted. As discussed above, this is the case in almost all European countries where private prosecutions are allowed. Another important limitation could be that there should be cases where public prosecutors are allowed to intervene and take over private prosecutions for the purpose of either continuing with them as public prosecutions or for the purpose of discontinuing them. Such a possibility exists already in some countries such as the United Kingdom ${ }^{190}$ and Croatia. ${ }^{191}$ This would ensure, for example, that private prosecutions are not abused. In such cases, however, the decision of the public prosecutor to take over a private prosecution should be based on reasonable grounds that have to be given to the satisfaction of

\footnotetext{
${ }^{187}$ Case C-404/07, György Katz v István Roland Sós (Opinion of Advocate General Kokott) (10 July 2008) para. 39.

188 Case C-404/07, György Katz v István Roland Sós (Opinion of Advocate General Kokott) (10 July 2008) para. 31.

189 The court states that 'In comparison with the powers of the public prosecutor, the powers of the party bringing a substitute private prosecution are limited in so far as he may not propose that the accused be deprived of parental authority, he cannot have access to confidential documents which are separated from the file, and he cannot extend the charge.' See Case C-404/07, György Katz v István Roland Sós (Opinion of Advocate General Kokott) (10 July 2008) para. 6.

${ }^{190}$ See generally Gujra, R (on the application of) v Crown Prosecution Service [2013] 1 All er 612.

${ }^{191}$ Bilbija and Blažević v Croatia (Application No. 62870/13) (12 January 2016) para. 76.
} 
the court in which the prosecution is pending. The private prosecutor should also have a right to make submissions why the public prosecutor should not take over a private prosecution. In other words, if a victim of crime has a right to institute a private prosecution, a public prosecutor's decision to take over a private prosecution would have to be subject to court scrutiny. For example, if the public prosecutor finds that the suspect does not have a case to answer; this could be one of the grounds to limit the institution of a private prosecution. ${ }^{192}$ The provision of the right to institute a private prosecution would give victims' rights organisations a platform to either put pressure on states or work hand in hand with states to ensure that measures are put in place to give effect to this right. It would also ensure that victims approach the European Court of Human Rights challenging states' violation of such a right and ultimately the Court will develop jurisprudence to guide states on the measures needed to promote, protect and fulfil that right.

There have been instances where private prosecutions have been dismissed because the victim had filed it late. ${ }^{193}$ This means that there is a need for people to be educated on the circumstances in which they may institute such prosecutions. This could be one of the issues to be addressed in such guidelines. The issue of the manner in which an accused in a private prosecution may be brought to court may also be addressed in such guidelines. In countries such as Poland, an accused in a private prosecution may be detained awaiting trial. ${ }^{194}$

This is may not be the case in other countries. Another issue that could be addressed are the rights of crime victims in countries where subsidiary private prosecutions are permitted. This is in the light of the Court of Justice of the European Union's ruling on the right of crime victims to be heard in such prosecutions. The Court held that:

Under the first paragraph of Article 3 of Council Framework Decision 2001/220/jha of 15 March 2001 on the standing of victims in criminal proceedings, victims of crimes who act as prosecutor in lieu of a public prosecutor in the resulting criminal proceedings must have the possibility of contributing evidence in the proceedings by giving testimony. Such victims need not, however, be afforded the status of witnesses if the applicable national law governing criminal procedure nevertheless grants them the possibility of being heard before the court and that testimony constitutes admissible evidence. 195

Another issue that could be addressed by the guidelines is the relationship between extraditable offences and private prosecutions. In Ukraine, a court will not order the extradition of a suspect if the offence, in accordance with the law of the party requesting extradition, or Ukrainian law, can be prosecuted by means of a private prosecution.'196This may not be the case in other countries

\footnotetext{
${ }^{192}$ Procura della Repubblica v M Case C-398/12 (Opinion of Advocate General Sharpston delivered on 6 February 2014 (1)) para. 38 (as is the case in Belgium).

${ }^{193}$ Y v Latvia (Application No. 61183/08) (21 October 2014) para. 22.

${ }^{194}$ Ladent v Poland (Application No. 11036/03) 18 March 2008 para. 56.

195 Case C-404/07, György Katz v István Roland Sós (Opinion of Advocate General Kokott) (10 July 2008) para. 47. See also dg Justice Guidance Document, related to the transposition and implementation of Directive 2012/29/eu of the European Parliament and of the Council of 25 October 2012 establishing minimum standards on the rights, support and protection of victims of crime, and replacing Council Framework Decision 2001/220/jha, Ref. Ares(2013)3763804 - 19/12/2013, p. 29.

${ }^{196}$ See Resolution No. 16 of the Plenary Supreme Court of 8 October 2004 on certain issues relating to the application of legislation governing the procedure and length of detention (arrest) of persons awaiting extradition. Quoted in Soldatenko v Ukraine (Application No. 2440/07) 23 October 2008 para. 31.
} 
and impacts on extradition law. The guidelines may also deal with the rights of the accused in private prosecutions and the role of private prosecutors in ensuring that the accused's right to a fair trial is not violated. The Court of Justice of the European Union held that:

It should...be emphasised that giving effect to the position of victims bringing prosecutions should not entail any kind of diminution of the rights of the defence. These rights derive from the right to a fair trial, which is enshrined in Article 6 of the Convention for the Protection of Human Rights and Fundamental Freedoms...The rights of the defence, therefore, constitute a fundamental right forming part of the general principles of law whose observance the Court ensures. 197

Although there are international guidelines on the roles and responsibilities of public prosecutors, there are none on the role of private prosecutors. The result is that in some countries such as the United Kingdom courts have held that a private prosecutor does not have to prosecute without fear, favour or prejudice and that he may be a witness in the case he is prosecuting yet a public prosecutor is expected to do the opposite. 198 This should be understood in the light of the fact that, as has been illustrated above, the Court of Justice of the European Union held that even in cases of private prosecution, defence rights must be protected and that a substitute private prosecutor may not be a witness in a case he is prosecuting.

${ }^{197}$ Case C-404/07, György Katz v István Roland Sós (Opinion of Advocate General Kokott) (10 July 2008) para. 44.

${ }^{198}$ R (on the application of Haase) v Independent Adjudicator \& Ors [2007] ewhc 3079 (Admin) (20 December 2007 ) para. 34. 